Jurnal Teknologi Laboratorium

Vol.9, No.1, June 2020, pp. $115-120$

ISSN 2580-0191(Online), ISSN 2338 - 5634(Print)

DOI: 10.29238/teknolabjournal.v9i1.209

Journal homepage: https://www.teknolabjournal.com/index.php/Jt//index

Original Research

open 1 Access Does platelet/ lymphocyte ratio a predictor of CD34+ peripheral blood stem cell
yield in the healthy donors mobilized with GCSF?

\title{
Zafer Gokgoz
}

Department of Hematology, Faculty of Medicine, Yuksek İhtisas University, Turkey

E-mail address: drzafergokgoz@gmail.com

HIGHLIGHTS

Consequently, a high platelet/lymphocyte ratio may be correlated with the number of collected CD34+ stem cells

\section{ARTICLE INFO}

\section{Article history}

Received Date: March 04 $4^{\text {th }}, 2020$

Revised Date: June 01 ${ }^{\text {st }}, 2020$

Accepted Date: June 04 $4^{\text {th }}, 2020$

\section{Keywords}

Lymphocyte ratio

CD34+

Stem Cells

\begin{abstract}
A B S T R A C T
This research aimed to determine whether there is a correlation between platelet/lymphocyte ratio the number of collected CD34+ stem cells. This retrospective study included 94 adult related stem cell donors who were healthy and volunteer by screening their files between the years 2016 and 2018. All donors were mobilized using $2.5 \mathrm{mcg} / \mathrm{kg}$ lenograstim or filgrastim and underwent peripheral stem cell apheresis. Complete blood counts were tested at baseline before G-CSF administration (pre-G-CSF), and before PBSC collection after mobilization with G-CSF administration. The patients were divided into two groups as aged below and over 50 years old. From these comparative data, only BMI value of the group aged below 50 years was statistically significantly lower than the other group, whereas no statistically significant difference was found between the groups in terms of other parameters. The numbers of the collected CD34+ stem cells of both age groups were similar, and no significant difference was found. The values of platelet/lymphocyte ratio, early measurement of CD34+ stem cells and the amount of the collected CD34+ stem cells of both groups at the first and second days of the procedure were found similar. This research show that a high platelet count and consequently, a high platelet/lymphocyte ratio may be correlated with the number of collected CD34+ stem cells but our hypotheses revealed insignificant outcomes.
\end{abstract}

This is an open-access article under the CC-BY-SA license.

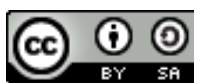

\section{*Corresponding Author:}

\section{Zafer Gokgoz}

Department of Hematology, Faculty of Medicine, Yuksek İhtisas University, Turkey

Karakaya Mahallesi, Baglum Bulvari No.1, 06291, Kecioren, Ankara, Turkey

E-mail: drzafergokgoz@gmail.com

Phone:+90 3123297425 


\section{INTRODUCTION}

Peripheral blood stem cell collection for allogeneic or autologous stem cell transplantation

has become the standard treatment modality thanks to easy-applicability and rapid haematological reconstitution compared with stem cell collection from bone marrow harvest in many malignant and benign cases., 1,2 Stem cell mobilization is performed with granulocyte-colony stimulating factor (GCSF) in healthy donors. The donor response to G-CSF influences the number of CD34+ cells and eventually transplantation outcomes. Low level of peripheral blood stem cell increases the risk for graft failure. -3 On the other hand, transplantation of high CD34+ stem cell doses increases the risk for acute graft versus host disease (GVHD). ${ }^{4}$ Nevertheless, a high level of stem cell infusion in the patient is considered to be associated with faster immune reconstruction. -5 As known, GCSF causes lymphocytosis, however, GCSF has several effects on T-cell subgroups such as especially mobilization of naive $T$ lymphocytes, reduced adhesion molecules and chemokine receptors, reduced T-helper-1-related cytokines and increased regulatory $\mathrm{T}$ (T-reg) cells. ${ }^{-}$It is also known that GCSF suppresses pro-inflammatory cytokines and increases secretion of IL-10. All these effects indicate the immunosuppressive nature of GCSF in healthy humans. ${ }^{\geq}$On the other hand, it has been shown that platelet count in the peripheral circulation decreases due to G-CSF administration. $-\frac{8}{}$ The reduction in platelet count is directly proportional with GCSF dose. ${ }^{9}$ Baseline platelet counts prior to the onset of GCSF administration is strongly correlated with the amount of mobilized CD34+ stem cells. $\frac{10,11}{11}$

In the light of all these information from the literature, we have retrospectively evaluated whether there is a correlation between the platelet/lymphocyte ratio as a cheap and easyapplicable method and the number of collected CD34+ stem cells.

\section{MATERIAL AND METHOD}

This retrospective study included 94 adult related stem cell donors who were healthy and volunteer by screening their files in the Bone Marrow Transplant Unit of Medicana Ankara International Hospital between the years 2016 and 2018 (Ethics Committee Approval Dated 08.02.2019, Number:26). All donors were over 18 years old. A haematologist from the bone marrow transplant team approved the donors by evaluating their detailed anamnesis, physical examination, complete blood count, biochemistry and infection markers, blood grouping and $\mathrm{Rh}$ typing, and pregnancy testing in the females of childbearing age. The donors with a chronic disease and ongoing medication were excluded from the study. Body mass index (BMI) was calculated according to the formula $\mathrm{BMI}=$ weight (in kilograms)/height (in meters squared). All donors were mobilized using $2.5 \mathrm{mcg} / \mathrm{kg}$ lenograstim or filgrastim and underwent peripheral stem cell apheresis.

The onset of G-CSF administration was accepted as the 1st day, and the donors underwent mobilization procedure with Fresenius (Bad Homburg, Germany) device if the early measurement of CD34+stem cells resulted in $20 \times 10^{6} / \mathrm{L}$ at the 5 th day. The collection of minimum $2 \times 10^{6} / \mathrm{kg}$ body weight CD34+ stem cells was targeted. The donors underwent apheresis procedure for 1 or 2 days according to that target cell dose or transplant planning of the patient. The blood volumes were processed for 2-4 times and coagulated with 40-90 mL/minute acidcitrate dextrose as the coagulant in the healthy donors (HD) determined to be performed the procedure at the second day. The healthy donors (HD) were administered $10 \%$ Calcium Gluconate. Complete blood counts were tested at baseline before G-CSF administration (pre-GCSF), and before PBSC collection after mobilization with G-CSF administration.

The parameters were analyzed by SPSS for Windows Version 23.0. The continuous variables were expressed as median (minimum-maximum); numbers while percentages were used to express categorical variables. The differences between continuous variables of two groups were calculated by Mann-Whitney-U test. The repeated measures were compared by Wilcoxon test. Chi-square test was used in the analysis of categorical parameters. Spearman Rho 
correlation was used to calculate the correlation of two continuous variables. The $p<0.05$ value was accepted as the statistical significance level.

\section{RESULTS AND DISCUSSION}

Totally 94 donors were included in the study. The study group consisted of 38 females and 56 males. The patients were divided into two groups as aged below and over 50 years old. This distribution was based on the consideration that the platelet/lymphocyte ratio may have an impact on the amount of CD34+ stem cells depending on donor age. Median haemoglobin $(\mathrm{Hg})$ value was $15 \mathrm{~g} / \mathrm{dl}$ in the group aged below 50 years, whereas that value was $14.7 \mathrm{~g} / \mathrm{dl}$ in the group aged $\geq 50$ years. WBC counts of the groups were found $7.08 \times 10^{3} / \mathrm{mL}$ and $7.24 \times 10^{3} / \mathrm{mL}$, respectively. Body mass index (BMI) value of the younger group was 24.9 , whereas that value was 27.8 in the group aged $\geq 50$ years (Table 1 ). From these comparative data, only BMI value of the group aged below 50 years was statistically significantly lower than the other group, whereas no statistically significant difference was found between the groups in terms of other parameters. The numbers of the collected CD34+ stem cells of both age groups were similar, and no significant difference was found (Table 2). In addition, we have analyzed the platelet/lymphocyte counts in two groups as $<100$ and $>100$ (Table 3). The values of platelet/lymphocyte ratio, early measurement of CD34+ stem cells and the amount of the collected CD34+ stem cells of both groups at the first and second days of the procedure were found similar.

In the present study, we have analyzed the relationship between baseline platelet/lymphocyte ratio and the amount of CD34+ stem cells collected following mobilization. The previous studies have suggested assumptions on predicting a number of the CD34+ stem cells based on various demographic and laboratory analyses and reported that the most effective factors on CD34+ stem cell apheresis yield are G-CSF dose administered in the donor as well as age, gender and the bodyweight of the donor, $\frac{10}{}$ however, no study on platelet/lymphocyte ratio has been conducted yet as far as we know. It has been aimed to predict the amount of CD34+ stem cells that can be collected by performing an easy and low-cost method in this study.

The peripheral blood stem cell collection from healthy donors induced with GCSF is an easy technique with a low incidence of complication. The amount of the collected CD34+ stem cells has various effects on engraftment. The detection of these effects in the early pretransplantation period is important in the regulation and prediction of the posttransplantation period.

It is known that a high level of baseline platelet count before GCSF administration is proportional to the number of mobilized CD34+ stem cells. 10,11,12 In the present study, we did not analyze the relationship of platelet count with baseline value before GCSF administration and number of the CD34+ stem cells before the procedure. In addition, some studies have suggested that the amount of the collected stem cells may decrease with advancing age, whereas some other studies assert the contrary to this conclusion. $\underline{13}$ Various studies on donor age have presented different outcomes. $\frac{14,15}{15}$ De La Rubia et al. have reported that a higher number of CD34+ stem cells was collected in the younger donors. From this point of view, we distributed our donors into two groups as ones aged below and over 50 years old. We have determined that the platelet/lymphocyte ratio was not significantly correlated with the amount of CD34+ stem cells in both groups.

Our study has some limitations. As our study is retrospective, we could not obtain lymphocyte subgroups and also it would be better if we could search interleukins, tumour necrosis factors, and interferon-alpha because these mediators are effected by GCSF also, if we could not use one type of generic for all donors we had to use filgrastim or lenograstim both. 


\section{CONCLUSION}

As an overall conclusion, we have assumed that a high platelet count and consequently a high platelet/lymphocyte ratio may be correlated with the number of collected CD34+ stem cells or contrarily a platelet/lymphocyte ratio encountered below a certain threshold value due to extremely reduced platelet count after GCSF administration may also be proportional with the collected CD34+ stem cells in developing hypotheses of the study. However, both of our hypotheses revealed insignificant outcomes.

\section{DISCLOSURE STATEMENT}

The authors reported no potential conflict of interest.

\section{FUNDING INFORMATION}

The authors declared that this case had received no financial support.

\section{REFERENCES}

1. Gratwohl A, Baldomero $\mathrm{H}$, Schmid O, Horisberger B, Bargetzi M, Urbano-Ispizua A. Change in stem cell source for hematopoietic stem cell transplantation (HSCT) in Europe: a report of the EBMT activity survey 2003. Bone Marrow Transplant. 2005;36(7):575-590. doi:10.1038/sj.bmt.1705104.

2. Bensinger WI, Martin PJ, Storer B, et al. Transplantation of Bone Marrow as Compared with Peripheral-Blood Cells from HLA-Identical Relatives in Patients with Hematologic Cancers. N Engl J Med. 2001;344(3):175-181. doi:10.1056/NEJM200101183440303.

3. Storb R, Prentice RL, Thomas ED. Marrow Transplantation for Treatment of Aplastic Anemia. N Engl J Med. 1977;296(2):61-66. doi:10.1056/NEJM197701132960201.

4. Przepiorka D, Smith TL, Folloder J, et al. Risk factors for acute graft-versus-host disease after allogeneic blood stem cell transplantation. Blood. 1999;94(4):1465-1470. http://www.ncbi.nlm.nih.gov/pubmed/10438735.

5. Savani BN, Rezvani K, Mielke S, et al. Factors associated with early molecular remission after $\mathrm{T}$ cell-depleted allogeneic stem cell transplantation for chronic myelogenous leukemia. Blood. 2006;107(4):1688-1695. doi:10.1182/blood-2005-05-1897.

6. Ringden O, Barrett AJ, Zhang M-J, et al. Decreased treatment failure in recipients of HLAidentical bone marrow or peripheral blood stem cell transplants with high CD34 cell doses. Br J Haematol. 2003;121(6):874-885. doi:10.1046/j.1365-2141.2003.04364.x.

7. Melve GK, Ersvær E, Kittang AO, Bruserud $\varnothing$. The chemokine system in allogeneic stemcell transplantation: a possible therapeutic target? Expert Rev Hematol. 2011;4(5):563576. doi:10.1586/ehm.11.54.

8. Falanga A, Marchetti M, Evangelista V, et al. Neutrophil activation and hemostatic changes in healthy donors receiving granulocyte colony-stimulating factor. Blood. 1999;93(8):25062514. http://www.ncbi.nlm.nih.gov/pubmed/10194429.

9. Tassi C, Tazzari PL, Bonifazi F, et al. Short- and long-term haematological surveillance of healthy donors of allogeneic peripheral haematopoietic progenitors mobilized with G-CSF: a single institution prospective study. Bone Marrow Transplant. 2005;36(4):289-294. doi:10.1038/sj.bmt.1705066.

10. Vasu S, Leitman SF, Tisdale JF, et al. Donor demographic and laboratory predictors of allogeneic peripheral blood stem cell mobilization in an ethnically diverse population. Blood. 2008;112(5):2092-2100. doi:10.1182/blood-2008-03-143677.

11. Zubair AC, Grant R, Wu W, et al. Platelet count is a sensitive predictor of autologous peripheral blood progenitor cell collection yield in previously treated plasma cell disease patients. Transfusion. 2008;48(6):1106-1114. doi:10.1111/.1537-2995.2008.01651.x.

12. Suzuya $H$, Watanabe $T$, Nakagawa $R$, et al. Factors associated with granulocyte colony- 
stimulating factor-induced peripheral blood stem cell yield in healthy donors. Vox Sang. 2005;89(4):229-235. doi:10.1111/j.1423-0410.2005.00701.x.

13. Anderlini P, Przepiorka D, Seong C, et al. Factors affecting mobilization of CD34+ cells in normal donors treated with filgrastim. Transfusion. 1997;37(5):507-512. doi:10.1046/j.1537-2995.1997.37597293882.x.

14. Favre G, Beksaç M, Bacigalupo A, et al. Differences between graft product and donor side effects following bone marrow or stem cell donation. Bone Marrow Transplant. 2003;32(9):873-880. doi:10.1038/sj.bmt.1704245.

15. De Lavallade $\mathrm{H}$, Ladaique $\mathrm{P}$, Lemarié $\mathrm{C}$, et al. Older age does not influence allogeneic peripheral blood stem cell mobilization in a donor population of mostly white ethnic origin. Blood. 2009;113(8):1868-1869. doi:10.1182/blood-2008-11-187773.

Table 1. The demographic characteristics of the donors

\begin{tabular}{|c|c|c|c|}
\hline & & & \\
\hline & $\begin{array}{c}<50 \text { of age } \\
(n=54)\end{array}$ & $\begin{array}{c}\geq 50 \text { of age } \\
(n=40)\end{array}$ & $\mathbf{p}$ \\
\hline & Media & n (\%) & \\
\hline Gender & & & $0.724^{\star \star}$ \\
\hline Female & $21(38.9 \%)$ & $17(42.5 \%)$ & \\
\hline Male & $33(61.1 \%)$ & $23(57.5 \%)$ & \\
\hline $\mathrm{Hgb}(\mathrm{mg} / \mathrm{dL})$ & $15(9.5-17.3)$ & $14.7(11.3-16.7)$ & $0.857^{*}$ \\
\hline WBC $\left(\times 10^{3} / \mu \mathrm{L}\right)$ & $7.08(4.02-11.7)$ & $7.24(4.39-11.3)$ & $0.731^{*}$ \\
\hline Weight (kg) & $73.5(50-102)$ & $79(50-107)$ & $0.096^{*}$ \\
\hline Height $(\mathrm{cm})$ & $170(153-188)$ & $169(148-180)$ & $0.016^{\star}$ \\
\hline BMI $\left(\mathrm{kg} / \mathrm{m}^{2}\right)$ & $24.94(18.94-35.71)$ & $27.8(20.52-40.27)$ & $0.001^{*}$ \\
\hline
\end{tabular}

*Mann Whitney-U test. ${ }^{* *}$ Chi-square test

Table 2. Efficacy and effect of HSC mobilization according to age group of the donors

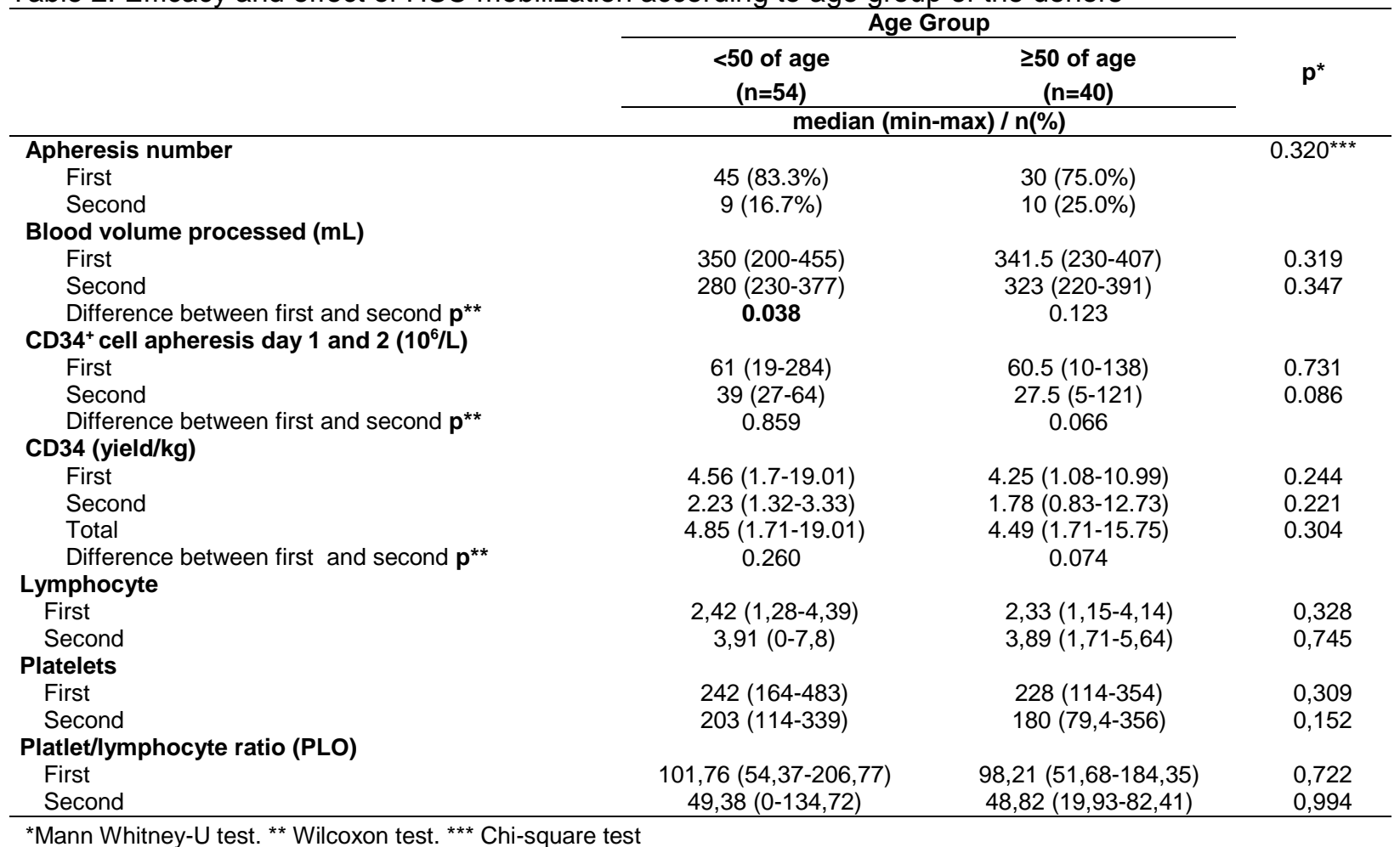


Table 3. Platelet lymphocyte ratio comparisons

\begin{tabular}{|c|c|c|c|c|c|c|}
\hline & \multicolumn{2}{|c|}{ PLO_1 } & \multirow[t]{2}{*}{$\mathbf{p}$} & \multicolumn{2}{|c|}{ PLO_2 } & \multirow[t]{2}{*}{$\mathbf{p}$} \\
\hline & $<100$ & $\geq 100$ & & $<100$ & $\geq 100$ & \\
\hline $\begin{array}{l}\text { CD34 count (apheresis } \\
\text { day 1) }\end{array}$ & $61(10-215)$ & $60.5(19-284)$ & 0.967 & $61(10-284)$ & $37(37-37)$ & 0.246 \\
\hline $\begin{array}{l}\text { CD34 count (apheresis } \\
\text { day } 2 \text { ) }\end{array}$ & $24(5-55)$ & $38(16-121)$ & 0.272 & $38(5-121)$ & $28(28-28)$ & 0.584 \\
\hline CD34_kg_1 & $4.41(1.08-18.3)$ & $4.32(1.64-19.01)$ & 0.487 & $4.4(1.08-19.01)$ & $2.75(2.75-2.75)$ & 0.261 \\
\hline CD34_kg_2 & $1.88(0.83-3.33)$ & $2.12(1.32-12.73)$ & 0.353 & $2(0.83-12.73)$ & $2.54(2.54-2.54)$ & 0.465 \\
\hline CD34 kg T & $4.67(1.98-18.3)$ & $4.65(1.71-19.01)$ & 0.800 & $4.66(1.71-19.01)$ & $5.29(5.29-5.29)$ & 0.699 \\
\hline
\end{tabular}

